\title{
Reconstructing North America: The Borderlands of Juan Cortina and Louis Riel in an Age of National Consolidation
}

Benjamin H. Johnson

Loyola University Chicago, bjohnson25@luc.edu

Follow this and additional works at: https://ecommons.luc.edu/history_facpubs

Part of the History Commons

\section{Recommended Citation}

Johnson, Benjamin H.. Reconstructing North America: The Borderlands of Juan Cortina and Louis Riel in an Age of National Consolidation. Remaking North American Sovereignty: State Transformation in the 1860s, , : 200-219, 2020. Retrieved from Loyola eCommons, History: Faculty Publications and Other Works,

This Book Chapter is brought to you for free and open access by the Faculty Publications and Other Works by Department at Loyola eCommons. It has been accepted for inclusion in History: Faculty Publications and Other Works by an authorized administrator of Loyola eCommons. For more information, please contact ecommons@luc.edu.

\section{(c) (†) $\ominus$}

This work is licensed under a Creative Commons Attribution-Noncommercial-No Derivative Works 3.0 License. (c) Fordham University Press, 2020. 


\title{
Reconstructing North America
}

\author{
The Borderlands of Juan Cortina \\ and Louis Riel in an Age of National \\ Consolidation
}

Benjamin H. Johnson

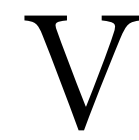

iewed from a continental perspective, the consolidation of national sovereignty in mid-nineteenth-century North America was a matter of three comparatively strong central governments, with some basis in popular sovereignty, conquering or incorporating other powers claiming sovereignty. Seen from above, as if looking down on a modern map or computer screen, one would see these three powers emerge-sequentially, the United States, Mexico, and Canada-and spread whatever colors the mapmaker chose to denote them across the continent's map. A more complicated representation might show a darkening of each color within national boundaries to represent the greater uniformity of sovereign power, as national law and authority became more uniform in the domain of their sovereignty.

Sovereignty has always been a matter of competing and contested claims. To nationalize the continent, these three states had to avoid the centrifugal forces of disunion within their boundaries (a loose confederation for Mexico, secession by New England or nullification by southern U.S. states, the persistent challenges of holding the loyalty of French Catholics in a polity controlled by English Protestants in British North America) and sometimes breakaway provinces and regions (Yucatán and Tabasco in Mexico, the Kingdom of Deseret and the Confederacy in the United States). And, of course, in a sense all three states were empires, conquering and subordinating the continent's native polities as well as occasionally fighting one another.

Canada, Mexico, and the United States were different countries born out of distinct (if interconnected) circumstances. All three were premised on the idea that legitimate sovereignty derived from the consent or support of the governed. Even Canada, which is not a republic and which Andrew Smith points out in this volume chose to remain a part of empire, emerged in the 1860 os a 
single state and legal system with provisions for self-government rather than the widely disparate relations that the British crown had previously conducted with the different regions and peoples. Yet despite their differences, all three governments posed similar challenges for peoples living beyond their effective reach. One of the benefits of examining national histories from border areas, the approach taken in this essay, is to draw attention to the parallel histories of seemingly different states and seemingly isolated areas and communities. Despite their distinct genealogies, reigning ideologies, and legal systems, all three of these states were intent on extinguishing competing sovereignties in the territory that they claimed as their own. Indeed, unlike the empires from which they emerged, for these nation states territoriality took on a heightened importance. For them, sovereignty meant the trinity of state, territory, and identity. As Abraham Lincoln told his Congress in 1862, in the midst of the U.S. Civil War,

A nation may be said to consist of its territory, its people, and its laws. The territory is the only part which is of certain durability. "One generation passeth away, and another generation cometh, but the earth abideth forever." ... That portion of the earth's surface which is owned and inhabited by the people of the United States, is well adapted to be the home of one national family, and it is not well adapted for two, or more. Its vast extent, and its variety of climate and productions, are of advantage ... for one people, whatever they might have been in former ages. ${ }^{1}$

As Charles Maier and Saskia Sassen argue in different ways, this North American emphasis on the territorial aspects of sovereignty mirrors a wider development across much of the globe, in which an "enhanced concept of territory" appealed to empires and newly consolidated nation-states. ${ }^{2}$

By the mid-nineteenth century, these states and their insistence on destroying other claims to sovereignty within their territory posed stark challenges to peoples who used to live beyond their effective reach. On the one hand, some of these peoples engaged in military resistance, epitomized by the Indian wars of the American plains; the similar pressures by Canada on the Lakota, Métis, and others; and the difficult conquest of Apaches and Yaqui in Arizona and Sonora. Others sought incorporation on equitable terms, with Tejanos and Nuevo Mexicanos going so far as to enlist in the Union Army during the U.S. Civil War, and caudillos in the Mexican Northeast jostling for continued regional autonomy within a Mexican national project. 
This essay focuses on two borderland regions that gave rise to regional leaders who both fought and embraced central governments, from the eve of the U.S. Civil War to 1885. Manitoba's Louis Riel and South Texas's Juan Cortina exhibit striking parallels: Both bore arms against the central states claiming their homeland, both justified their actions in terms of the very republican notions that undergirded those nations' claims to sovereignty, both expressed some willingness to acknowledge the legitimacy of the nations they fought against, and both held public offices in their native lands and in the United States. And both met unhappy ends for doing so: Cortina languished in jail for nearly twenty years until shortly before his 1894 death, and Riel was hanged for treason in 1885 .

Riel and Cortina embraced much of the ideology of republicanism in their insistence that borderland communities display the political virtues and coherence that gave them the right to form ties with different nations as they themselves saw fit. ${ }^{3}$ The discussions of legitimate authority and political and economic freedoms that roiled the North Atlantic world in the nineteenth century deeply shaped the communities on the peripheries of the emerging national governments of North America from which the two men emerged. This under-explored intellectual history means that the nationalization of North America represented not only a military victory of three nations over other polities, but also the eclipse of more consensual and multilateral understandings of national belonging.

Riel and Cortina remain compelling figures long after their deaths in part because their relations with the states of Mexico, Canada, and the United States reflect some of the enduring paradoxes of nation-building in North America. What political or moral valence should we attach to the nationalization of North America? Is this history a triumph or a tragedy? Neither or both? The close ties between nation-states and the rise of history as a modern academic discipline in the late nineteenth century, to say nothing of ethnocentrism, ensured that early accounts of Métis and border Mexicans dismissed people like Riel and Cortina as marginal curiosities, mere bandits, or (in Riel's case in particular) as lunatics. Younger, more inclusive nationalist accounts continued to celebrate the nationalization of the continent as a great step forward for freedom. And with good reason: in the U.S. context, Lincoln's insistence that Americans were "one people, whatever they might have been in former ages" justified not only the Union triumph on the battlefield, but also the extension of civil and political rights to the four million enslaved people liberated by that triumph. One might well tell a similar story about Juárez's defeat of Maximilian. Nations have indeed been emancipatory for their citizens. 
On the other hand, these nations and the republican notions of sovereignty that served as their ideological basis were disasters for borderland peoples. This is a major argument of both the "New Western History" that emerged in the late 198 os and the more recent flowering of Native American history, whose portrayal of the United States as a settler colonialist state is the dark flip side of the celebration of the virtues of the United States as the epitome of republican (and later, democratic) governance. The insistence that the residents of a nation constituted "one people" was also the basis for the systematic destruction of native sovereignties and cultures that all three of North America's nation-states have engaged in, to an appallingly greater extent than did the colonial empires from which they emerged. ${ }^{4}$ The nationalization of North America has brought us emancipation, the very idea of civil rights, and also tragic conquest and destruction. Lincoln's statement resonates in one way if we think of the emancipation of four million enslaved people, and in a very different, if equally strong, way if we think of Sand Creek or the Dakota War, just as the triumph of the Juaristas brought nothing good for Mexico's Indian peoples, and the exercise of Canadian sovereignty was a disaster for native peoples. Riel and Cortina take us right to the heart of this paradox: The nationalization of the continent was both triumph and tragedy.

\section{Borderland Rebels}

Although both men would one day cause tumult and divisiveness in national capitals, they were born far from the corridors of power. Juan Nepumuceno Cortina was born in 1824 in Camargo, Tamaulipas, into a prominent ranching family. His mother was one of the heirs to one of the largest land grants in the Mexican northeast, located just to the north of the Rio Bravo in what became Texas when the United States defeated Mexico in 1848. His father served as mayor of Camargo. Cortina fought with Mexican forces in their unsuccessful efforts to fend off the invading U.S. Army in 1846. Soon after the war, he moved north of the river, working for the U.S. quartermaster as a teamster and thereafter assembling his own cattle herd. In the $1850 \mathrm{os}$ his brother was elected tax assessor and collector for Cameron County, which included the important town of Brownsville. ${ }^{5}$ Riel was born twenty years later, in 1844, in the young Red River settlement in the domain of the Hudson's Bay Company, near what is now Winnipeg. His family enjoyed a similar regional prominence: Louis Riel, Sr., was a political and business leader of the colony who played key roles in mobilizations against the company's regulations. The Riel family was of mixed lineage, like most of the residents of Red 
River: Riel's mother's parents were some of the first European settlers in Red River, while his paternal grandparents were a French-Ojibwe family. Like his father, Riel for a time studied for the priesthood, in Quebec. He left behind his religious education, studied law for a time, worked for a while in St. Paul, Minnesota, and returned to Red River in 1868 .

Conflicts over land tenure and ethnicity catapulted both men into fame. Cortina grew increasingly upset at what he regarded as Anglo American usurpation of Spanish and Mexican land grants, including his mother's. In an 1859 visit to Brownsville, he saw an Anglo deputy sheriff beating a man who had worked on his family's ranches. Cortina shot the sheriff. After fleeing to Mexico for several months, he led a paramilitary force in the capture of Brownsville, where he evened scores with newly arrived Anglos and released several ethnic Mexicans from the town jail. Here he issued proclamations defending the safety, property, and autonomy of Hispanics under Anglo-American rule.

Cortina's foes mobilized Texas Rangers, units of the Mexican Army, and parts of the United States Army (under the command of Robert E. Lee, freshly arrived from suppressing John Brown's raid on Harper's Ferry). The resulting war lasted for nearly two years, laying waste to a region half the size of Connecticut. Forced into Mexico, Cortina remained a key player, running guns to Union partisans in Texas and fighting on the side of the Juárez government in the War of the French Intervention. For a time he was a claimant to the governorship of Tamaulipas, where he continued to be the scourge of south Texas Anglo ranching barons, until Porfirio Díaz removed him from power and subjected him to arrest beginning in 1877 . He remained a prisoner until shortly before his 1894 death. ${ }^{6}$

Cortina became a folk hero and a fixture of the history of Mexican Americans and the U.S.-Mexico border but never achieved the kind of continental and trans-Atlantic fame of Louis Riel. Riel led a similar rebellion in 1869, preventing the Canadian Confederation's appointed governor from entering the Red River district. Like Cortina, he epitomized the fears of his community that its economic independence, political power, and cultural integrity would be destroyed by an Anglo central government. At first, Riel's uprising looked to be much more successful, resulting in the creation of the province of Manitoba, with written protection for the French language and Métis landholding and political rights. Twice elected to Canadian parliament but prevented from taking his seat, Riel, like Cortina, fled to the nation to the south, where, also like Cortina, he became an officeholder (deputy sheriff) and ultimately a citizen. But the compromise in Manitoba came undone, and Métis who had moved west into Saskatchewan invited Riel back into Canada in 1884 . He became the figurehead of the North-West 
Rebellion the next year, was arrested upon its defeat, and was tried and executed for treason in November of 1885 . Riel fought the law, and the law won. ${ }^{7}$

Both men mobilized and spoke on behalf of distinctive regional and ethnic communities. Both condemned Anglo avarice-Cortina described Anglos as "flocks of vampires," a phrase that may still accurately describe Texas's political class. And indeed, the later struggles of Mexican Americans, Métis, and French Canadians account for the strong historical memories of Riel and Cortina. Yet what is striking about the language of their proclamations is not so much the invocation of distinct peoplehood and oppression because of their racial difference, but rather their invocation of republican political virtues and notions of sovereignty as derived from a social contract. Canada and the United States had no right to rule them without their consent.

In the first proclamation that he issued after taking Brownsville, Cortina invoked the "sacred right of self-preservation" and described a "popular meeting with a view of discussing a means by which to put an end to our misfortunes." In the second, he similarly began by discussing the importance of deliberation, consensus, and "public opinion" in instances of violent resistance. He went to some lengths to describe the region's ethnic Mexican community as demonstrating the republican virtues of productive labor and love of liberty. "The Mexicans who inhabit this wide region," he declared, "some because they were born therein, others because since the treaty [of] Guadalupe Hidalgo, they have been attracted to its soil by the soft influence of wise laws and the advantages of a free government ... are honorably and exclusively dedicated to the exercise of industry, guided" by the belief "that only in the reign of peace can he enjoy without inquietude the fruit of his labor." Moreover, as literary scholar Alberto Varon argues, Cortina presented himself as the embodiment of republican manhood, neither cowering before his enemies nor abusing his power in the exercise of indiscriminate violence. ${ }^{9}$

Cortina went to florid lengths to argue that the virtues of self-government, impartially administered law, and respect for property rights and free labor were the exclusive property of no single nation or people. Indeed, against the ethnic chauvinism of his foes, he suggested that governments derived their legitimacy from respect for whoever practiced these virtues. "Ever diligent and industrious, and desirous of enjoying the longed-for boon of liberty within the classic country of its origin," he said of Mexican Americans, "we were induced to naturalize ourselves in it and form a part of the [nation], flattered by the bright and peaceful prospect of living therein and inculcating in the bosoms of our children a feeling of gratitude towards a country beneath whose aegis we would have wrought 
their felicity and contributed with our conduct to give evidence to the whole world that all the aspirations of the Mexicans are confined to one only, that of being freemen; and that having secured this ourselves, those of the old country, notwithstanding their misfortunes, might have nothing to regret save the loss of a section of territory."10

Louis Riel's proclamations invoked a very similar language of republicanism. "The Declaration of the People of Rupert's Land and the North West," issued in December of 1869 to justify the establishment of a provisional government in defiance of Ottawa's wishes, sounds at first like a tract of political theory: "Whereas it is admitted by all men as a fundamental principle that the public authority commands the obedience and respect of its subjects. It is also admitted that a people, when it has no government, is free to adopt one form of Government in preference to another to give or to refuse allegiance to that which is proposed." Because Canada had not secured the consent of the Métis community, and had dispatched a military force, Riel and his compatriots argued that "we have but acted conformably to that sacred right [the same phrase as Cortina] which commands every citizen to offer energetic opposition to prevent his country being enslaved." Legitimate sovereignty, both men suggested, lay in republican self-government. ${ }^{11}$

Where did Riel, Cortina, and their leading lieutenants get their republican ideology? How and why did leaders of communities far removed from national print cultures and centers of education, and with low rates of literacy, craft such detailed and eloquent statements of republicanism so clearly in conversation with the larger orbits of the English, French, and Spanish worlds? These questions are especially acute in Cortina's case: The fact that he was illiterate and the florid language of the proclamations made it easy for hostile contemporaries and even many later historians to dismiss him as a windbag or a passive vessel for the more educated..$^{2}$

Yet in fact both men were heirs to long local traditions of republicanism, adapted to serve the needs of their communities. Starting before Riel's birth, Red River Métis had pushed for elected representation on the Council of Assiniboia, which was created by the Hudson's Bay Company to administer the law in its domains. ${ }^{13}$ Red River Métis practiced their own form of self-government in the management of the enormous buffalo hunts in which they engaged. By the 1820s, they mounted two hunts a year, a large one at the start of summer and a smaller in fall. By the time of Riel's birth, these expeditions employed as many as 1,200 of the community's distinctive Red River Carts, and could last two months. The complicated logistics of coordinating the movement of this many people, orga- 
nizing their efforts, processing the animals, and dividing the proceeds led to the development of well-articulated structures and principles of self-government outside the control of the Council or Company. There was an elected hunt leader and lieutenants, but their power lay not in written law or the machinery of state, but in their social power as representatives of the larger body of the settlement. These leaders also represented the Métis on the hunts to the outside world, especially to indigenous neighbors such as the Ojibwe and Dakota, with whom hunting parties often came into contact. ${ }^{14}$

Moreover, although the Red River settlement remained on the periphery of English and French print cultures alike, its residents had access to the formal debates about sovereignty raging in the Atlantic world in the age of independence. Father George Belcourt, an extraordinary Catholic missionary to the settlement, "taught Métis leaders the basic elements of liberalism with its call for the freedom of political expression and commercial intercourse." Fluent in Ojibwe as well as English and French, Belcourt had come to be a key civic advisor by the time of Riel's birth. ${ }^{15}$ Whereas clerics such as Belcourt essentially became a part of Red River Métis society, some Red River Métis looked outward to engage Atlantic political culture in more metropolitan institutions; the bishop of Red River's St. Boniface Parish actively recruited young Métis for the priesthood, for which Riel, like his father before him, studied for a time. His seven years at the Petit Séminaire of the Collège du Montréal surely exposed him to the Catholic scholastic tradition and its Thomistic emphasis on society rather than monarchs or states as the basis of legitimate political authority. Red River Métis lived far from the centers of wealth and power but were well acquainted with the pressing questions of sovereignty roiling the larger western world. ${ }^{16}$

Juan Cortina and his circles were located even more centrally in debates about sovereignty. It is easy to think of Texas, the northeastern province of New Spain and later Mexico, as an intellectual backwater: It had no universities and the first printing press arrived there only in 1817. Yet the Franciscan convent of Monterrey, Nuevo León, about one hundred miles south of the Rio Grande, provided the region's elite men with an opportunity to study law, philosophy, and political theory. The men who led the movement for Mexican independence in the northeast - a region where the struggle came earlier and stronger than in most of what became Mexico-availed themselves of this opportunity, particularly crediting Franciscan Father Bellido for introducing them to critiques of monarchy even as the Spanish Bourbons sought to purge such notions from their realms. These rebels invoked the good of a community more often than the individual rights that were more important to Anglo-American republicanism. They circulated their 
ideas by pronuncamientos, or manifestos, posted in public places and intended to be read aloud and heard by the community to which they appealed. The public recitation and hearing of these pronouncements, by large groups assembled in such places as the plazas that lay at the heart of Spanish-Mexican towns, was the counterpart to the more individualistic print culture of the north Atlantic world and to the council gatherings on the Métis bison hunts. ${ }^{17}$

This political tradition marked Juan Cortina's pronouncements. For a supposedly illiterate man, Cortina cared an awful lot about how he presented his actions and what the borderland public thought of them. In the aftermath of his Brownsville raid, he worked closely with Miguel Peña, a revolutionary and former Mexican Army officer who published a paper in Brownsville; with Jesús Ballí, one of his most socially prominent and best-educated lieutenants, and with his own brother, José María, a former tax collector widely thought of as a cerebral counterpart to his hot-headed younger sibling. The two proclamations he released explicitly invoked public opinion, followed the general mold of early revolutionary proclamations, and were published in both English and Spanish. After having been driven into Mexico, Cortina continued to publish a series of such proclamations throughout the tumultuous 1860s, justifying his actions in the war of the French Intervention as serving the republican cause embodied in the liberal constitution of 1857 . Pledging his support for Juárez and his embattled government in 1864, Cortina condemned "the invader" who installed an illegitimate government "emanating from the will of their bayonets." In 1870, he helped orchestrate the publication of a lengthy biographical pamphlet ostensibly published by "various citizens of Tamaulipas," first in Mexico City and then in Brownsville. Here he went to great lengths to rebut charges made against him by a French author writing about Emperor Maximilian's ill-fated regime. The pamphlet concluded by describing him as "a true republican soldier" who "has not shrunk from danger, when he has seen his soil profaned by the invader's foot." 18 Like Riel, Cortina went to great lengths to present himself as acting in accord with the ideas of republicanism.

\section{Changing Flags}

Taking into account these long traditions of republicanism allows us to understand the willingness of Riel, Cortina, and many of their foot soldiers to change national loyalties and citizenship. This practice is often attributed to mere opportunism by nineteenth-century observers and recent scholars alike, but as Eric Schlereth observes, many early nineteenth-century North Americans believed 
that the right to voluntary expatriation was a fundamental aspect of liberty. In this line of thought, articulated in eighteenth-century legal treatises by Emer de Vatel and Jean-Jacques Burlamaqui, the rights of individuals to affiliate themselves with nations to advance their own interests took primacy over the claims of nations to perpetual obedience. The United States Supreme Court recognized some rights to repatriation in 1804 and 1822, and Mexico did from its Independence. Canada wrote such a right into law in 1881, though it obviously refused to apply it to Riel. For his part, the Métis rebel made a series of desperate pleas to the U.S. consul in Winnipeg for diplomatic intervention on behalf of his rights as a citizen. The Grover Cleveland administration ignored these pleas, for which it was condemned in the U.S. Senate and press after Riel's execution. As Wilbur Bryant, a Nebraska attorney and judge argued forcefully,

It boots little that Louis Riel was Catholic or Protestant; that he was of French or Germanic, or of Indian, or of Irish, or of Swedish extraction; that he was patriot, fanatic, imposter or madman. For such purpose, it matters not whether he be considered a John Brown, a Count Cagliostro, an Anacharsis Clootz, a Don Quixote, a George Francis Train, or a William Tell. One proposition is beyond cavil: He was, at his death, an American citizen. That undisputed fact stamped upon him a dignity which neither race, religion, character or condition could obliterate. Civis Americanus fuit. Forget all beside. ${ }^{19}$

Cortina was more open about the voluntary nature of his claims to citizenship. For all of his condemnation of Texas and U.S. authorities, he insisted on his people's claims to U.S. citizenship, and indeed mocked his foes for turning to the Mexican army to assist in suppressing his revolt. He explained that, "separated as we are, by accident alone, from the other citizens of the city, and not having renounced our rights as North American citizens, we disapprove and energetically protest against the act of having caused a force of the national guards from Mexico to cross unto this side to engraft themselves in a question so foreign to their country that there is no excusing such weakness on the part of those who implored their aid." ${ }^{20}$ Such flexibilities exasperated Cortina's foes, as in the case of the army officer who reported that Cortina acted "at one time claiming to be an American, and at another a Mexican citizen." ${ }^{21}$

Cortina demonstrated that this commitment to some form of American nationalism was more then rhetorical several years later, when he and many fellow Texas Mexicans fought on behalf of the Union during the Civil War. Nearly one thousand Hispanic South Texans enlisted in the Union Army, many of them 
serving in the Second Texas Cavalry, which saw action as far away as Mississippi. The Confederate draft ensured that even more Tejanos would fight for the stars and bars. In April of 1861, prominent Cortina Lieutenant Antonio Ochoa led the Union forces in a bloody clash in the border county of Zapata, where his forces disavowed the allegiance to the Confederacy pledged by the county's judge, Isidro Vela, who had ensured that not a single Union vote was cast in the secession referendum. Vela defeated Ochoa's uprising for the time being, but, for the next five years, Cortina and allied Tejano unionists fought the forces of the Confederacy in South Texas by interdicting cotton shipments, killing prominent Confederates such as Vela, and smuggling weapons to Union armies. ${ }^{22}$

Many observers have depicted this support of the union in anti-political terms, as a reflection of local factionalism and straightforward self-interest rather than of any ideology or political beliefs. ${ }^{23}$ But self-interest and ideology are generally tied, no less for the planters of the South or the farmers of the North than for borderland ranchers. The clear class difference between Zapata County's Tejano unionists and confederates colored both their political interests and their ideology. The unionists' invocation of "Old Abe, rail splitter" suggests that they saw a kinship with the free labor ideology of the North, and the repeated complaints of slaveholders and pro-slavery Texans about border Mexicans' racial egalitarianism suggest that anti-slavery ideology also had a purchase in these communities. As an Anglo visitor to Rio Grande City wrote in 1858, "This admiration for Negroes somewhat disgusted me with the Mexicans." A pro-Confederate Brownsville paper made a similar point in the midst of the Civil War with its condemnation of the "lower order" of Mexican Texans as "not only abolitionists but amalgamationists." 24

Not all of Cortina's followers held unabashed enthusiasm for the Union, of course. Some had great difficulty in seeing the United States as a bearer of republican virtues, whatever their doubts about the Confederacy. Teodoro Zamora, one of Cortina's chief lieutenants, refused a commission in the Union's First Texas Cavalry. He wrote to Abraham Lincoln, chastising him for "trying to buy the influence of Cortina and his accomplices, offering them commissions, in order to render his supporters your supporters." But the "justice that God gave to all civilized nations" prevented Zamora from accepting the Union Army's offer. ${ }^{25}$

\section{Free Trade and Borderland Republicanism}

Their advocacy of free trade constituted another way in which Riel and Cortina, like other republicans, resisted the exclusive claims of central governments 
to exercise sovereignty. Their critiques of mercantilist restrictions on commerce bore striking resemblance to one another, and were both deeply rooted in the republican political traditions of their regions.

The contemporary politics of trade and protectionism are so driven by the desire of capital to escape national regulation in the name of larger social good that they make it difficult to see the very different debates surrounding these issues in the late eighteenth and nineteenth centuries. The rise of republican self-government as the basis of legitimate self-government in the western world enabled agrarian and early industrial capitalism in numerous ways, including by its validation of national territoriality. As Charles Maier and Saskia Sassen have emphasized, unlike the more mobile capital and more easily relocated production techniques and technologies of our own day, an emphasis on exclusive national sovereignty worked quite well for emerging capitalism. ${ }^{26}$ Yet republican ideology justified not only the nation-state as a political community designed to protect liberty, but also endowed individuals and (especially in Spanish republicanism) communities with the right to engage in advantageous trade, manufacture, and agriculture. There was, in other words, a realm of commerce that transcended the claims of governments. This ideology reflected the grievances of borderland communities that often felt themselves oppressed by distant and aloof governments.

Cortina and his followers were heirs to several generations of anti-mercantilist arguments offered by Spanish and Mexican republicans. Mercantilism, in which states aimed to control trade so as to foster metropolitan economic growth and to amass the largest possible stocks of precious metals, structured Spanish trade policy. The crown prohibited many local manufactures, and required all trade with the outside world to be conducted through the port of Veracruz, inconveniently located some 500 miles from the lower Rio Grande valley. Such measures chafed the residents of Spanish America. Attacks on mercantilism were major features of the anti-Spanish agitation that eventually led to the independence movements of the 1810s. In 1799, for example, the third known Spanish-language imprint published in the United States appeared in Philadelphia. It was a ninetypage tract entitled Reflexiones sobre el comercio de España con sus colonias en America ("Reflections on Spain's Commerce with Its Colonies in America"). The unnamed author relentlessly criticized Spanish trade policies. Invoking Scottish political economist Adam Smith, he argued that mercantilism had brought about "an absolute want of everything." Residents of places such as northern New Spain could not purchase, or could purchase only "at a most exorbitant price," such goods as "woolens, shoes, brandies, wines, and others of the same 
kind." Unless, of course, they violated the law and traded with more accessible American and British merchants, acts which could only "accustom themselves to depreciate the laws." Later, critics of Spanish rule who supported and instigated revolts in the 1810 similarly focused their ire on trade restrictions. These criticisms were not incidental, or merely technical matters of economic policy, but rather indicted the Spanish Crown for having betrayed its obligations to foster the welfare of Spanish Americans. What one author called "mercantile tyranny" proved that any monopoly, "of whatever kind it may be, carries along with it the principles of destruction, while under the influence of liberty, every thing prospers." The stifling of free trade was one way in which the crown had lost its legitimate authority. ${ }^{27}$

Attacks on monopolies, trading bans, and import restrictions in the name of the sovereignty of the people were not confined to the Hispanic world. "Next to a fort, arsenal, naval vessel, and military array," wrote U.S. abolitionist William Lloyd Garrison in 1847, "I hate a Custom House . . . as a matter of principle. I go for free trade and free intercommunication the world over, and deny the right of any body of men to erect geographical or national barriers in opposition to these natural, essential and sacred rights." ${ }^{28}$ Although Garrison's declaration, made in a private letter, never reached the ears of the Red River Métis, they and their allies had made similar pronouncements for more than a generation before the Riel Rebellion. Starting in the 183os, influential Métis traders began a campaign of withering attacks on the legitimacy of the Hudson's Bay Company monopoly. They not only argued that as natives, Métis ought to be exempt from the royal grant of monopoly privileges to the Company, but invoked wider republican critiques of monopoly and free trade. In 1846, an outright revolt against the company over its fur monopoly and control over consumer goods was narrowly averted, in larger part due to Father George Belcourt's urging the disaffected to submit their grievances to the British governor and crown. ${ }^{29}$

Their spokesman in England, the Red River-born William Isbister, advanced relentless critiques of monopoly in A Few Words on the Hudson's Bay Company, published in London. He opened the pamphlet with a dismissal of the company as "the only survivor of the numerous exclusive bodies which at one time depressed almost every branch of British commerce," made his case for the legal weakness of the company's claims, and attached petitions from European, Métis, and native Red River residents. The company's monopoly and arrest of those who sought other markets for furs and pemmican, wrote these petitioners, meant that "the natives, who are the original owners of the soil, have their energies and hopes completely paralysed and are doomed." Not only did the monopoly ensure that 
hard work was not rewarded, but it defied the common British practice of free trade that was "so powerfully maintained in all other possessions of our august Sovereign," as the more than one thousand native petitioners argued. The result was that the Métis and other inhabitants lived under a "kind of slavery."30

Economic dynamics ensured that republican notions of free trade held particular appeal for the residents of northeastern New Spain (which, of course, became the Mexican Northeast in 1821, a disputed borderland with the Texas Republic in 1836, and then the US-Mexico border with Texas annexation in 1845). Maritime and overland ties to the key commercial entrepôt of New Orleans put the burgeoning U.S. market within easy reach starting in the late eighteen century. The lower prices and higher quality of American manufactured goods and textiles was one side of the coin, while the prospect of selling cattle hides and cotton was the other. Little wonder that in 1822, when the first governor of the Mexican province of Texas, an old revolutionary, first addressed Texas's population, he declared to them that "you are free," which meant among other things that "you are going to freely engage with other nations."31 Northeastern Mexican leaders, despite the obvious acrimony generated by the Texas Revolution and U.S.-Mexico War, consistently pushed for permissive trade regulations to allow them access to Texas and U.S. markets. Secessionist efforts such as the proposed Republic of the Sierra Madre emphasized restrictions on trade as reasons for breaking away from Mexico. In the midst of the U.S.-Mexico War, for example, discontented northern Mexicans briefly published a newspaper from Matamoros called La República del Rio Grande y Amigo del Pueblo. The paper's first issue urged its readers to support the secession of the Northeast and to resurrect the ill-fated Republic of the Rio Grande. "Abandon the Mexican vulture, that preys upon your vitals," it urged, "the fitting symbol of a government that has no deeper commiseration for your sufferings, than the voracious bird upon her crest feels for the serpent that writhes in his beak." The second issue consisted of a sustained attack on the Mexican tariff and a familiar invocation of the benefits that free trade with the United States would bring to residents of the Mexican northeast. ${ }^{32} \mathrm{~A}$ few years later, when a similar group of northerners proposed a similar breakaway "Republic of the Sierra Madre," five of the twelve provisions of their plan concerned liberalizing a trade and tariff regime. ${ }^{33}$

Such sentiments continued after the war, though without the outright rejection of Mexican sovereignty sometimes associated with earlier efforts. Northern leaders pushed for a zona libre, or free zone, along the border, to allow the border strip to remain free of the tariffs that the Mexican government, like most states, relied on for its tax revenue. They enjoyed some success in convincing officials 
of the central government that such an allowance would better uphold national sovereignty than the doomed task of enforcing high customs duties (30 to 40 percent) along a porous border. The border area of Tamaulipas was first granted zona libre status in 1849, just ten years before Cortina's revolt, allowing goods destined for local consumption to be imported duty-free. The Mexican government extended similar measures to the entirety of its northern border until $1905 .{ }^{34}$

The economic circumstances of the Red River colony similarly made arguments over free trade central matters of the colony's politics. The Hudson's Bay Company depended on deliveries to York Factory on distant Hudson's Bay for the manufactured goods that it exchanged for furs. South of the border, the absorption of the Midwest into the United States, particularly the establishment of Fort Snelling in what became St. Paul in 1825 , brought a larger and better-developed market into close proximity to the Red River settlements. As in the Mexican Northeast, residents chafed at the economic impositions of the sovereign that ruled them. American traders established posts along the 49th parallel, inviting Métis and natives to sell the furs that the Hudson's Bay Company claimed as its own. The establishment of a trading post at Pembina in 1845 , located just two miles south of the border, intensified this dynamic, beckoning Métis and others to shift their operations just slightly south on the Red River. In Pembina, where many Métis soon lived, goods such as tobacco, whiskey, and sugar could be bought for less and furs, hides, and tongues sold for more. ${ }^{35}$

The company met this challenge by doing what it could to offer better terms of trade. Company officials also implemented more currency restrictions and "increased import duties, detentions, and searches." Matters again came to a head in 1849, when Pierre Guillame Sayer was charged with trading furs in Pembina. A crowd of three hundred armed Métis surrounded the courthouse in Fort Garry (now Winnipeg). Although the jury found Sayer guilty, the judge declined to fine or incarcerate him. Shouting "Le commerce est libre! Le commerce est libre!" among other slogans, the Métis crowd, whose organizers included Louis Riel's father, celebrated what they rightly considered to be a victory over the Hudson's Bay Company. As O. O. van Otter concludes, "[T]he Métis obviously had learned to use the rhetoric of liberalism-the arguments for representative institutions and free trade-as well as the power of its tools - the petitions laden with signatures. Their leaders, who articulated the needs and wishes of their people and enjoyed their support, understood the dominant mindset of the period."36

This long history of conflict over the economic controls of the Hudson's Bay Company, so closely tied to the republican ideals that circulated in Red River, found its way into the public pronouncements of the Red River Rebellion. The 
"List of Rights" issued by Riel and his compatriots continued this tradition of free trade republicanism in its calls for Canada to establish "steam connection between Winnipeg and Lake Superior" and "tighter" rail links between Winnipeg and St. Paul. In calling for recognition of the right of self-rule for their own distinct political community, they were just as insistent on linking the Red River district to the rest of Canada and to the United States. The rebels also insisted that import duties on all goods besides alcohol be frozen for three years, at which point they assumed that greater integration with the rest of Canada would make for a working market. Like the Mexicans of the Northeast, the Métis rebels insisted that legitimate sovereignty respect the rights of trade as well as of formal political representation. ${ }^{37}$

\section{Conclusion}

The "Cortina War" and the Northwest Rebellion were bitter defeats for the border-straddling communities that gave rise to Louis Riel and Juan Cortina. Both Métis and ethnic Mexicans saw their longstanding aspirations for autonomy and self-determination replaced by violent incorporation into national communities. Later stages of the imposition of Canadian and U.S. sovereignty in Cortina and Riel's homelands saw property regimes and legal systems further marginalize ethnic Mexicans and Métis in both economic and political terms. Little wonder, then, that subsequent generations of borderlanders, discontent with these societies, saw Riel and Cortina as implacable foes of Canadian and American rule. Yet the tragedy lay not only in what befell these communities in a material sense, but also in the foreclosure of the possibility of equitable belonging that had once beckoned Juan Cortina, Louis Riel, and their countless followers.

\section{Notes}

1. Abraham Lincoln, "Annual Message to Congress [December 1, 1862]," in Lincoln: Speeches and Writings, 1859-1865 (New York: Library of America, 1989), 403.

2. Charles Maier, "Consigning the Twentieth Century to History: Alternative Narratives for the Modern Era," American Historical Review 105 (June 200o): 816, 818; Saskia Sassen, "Territory and Territoriality in the Global Economy," International Sociology 15 , no. 2 (June 2000): 372-94; Sassen, Territory, Authority, Rights: From Medieval to Global Assemblages (Princeton: Princeton University Press, 2006). Maier defines this notion of territoriality "as a bounded geographical space that provides a basis for material resources, political power, and common allegiance" ("Consigning the Twentieth Century," 823).

3. Historians have had a notoriously difficult time defining "republicanism" with much specificity, especially enough to distinguish it from the related but sometimes 
conflicting ideas of liberalism and democracy. I use "republicanism" in this essay in a minimalist sense, to invoke the idea that legitimate governments are constituted by discrete communities that possess the civic virtues that enable rational self-rule (rather than by the force of a tyrant or the weight of tradition). Republicanism shares notions of individual autonomy and rights with the more individualistic and atomistic tradition of liberalism; in some contexts and for some authors, a republic differs from a democracy, while for others they are close cousins or democracy even the rightful heir to republicanism. As with all concepts used by historical actors and historians across broad expanses of time and place (western classical antiquity; early modern city-states in Europe; revolutionary France, Haiti, and the United States; Latin America in the early nineteenth century; numerous parts of the Atlantic world in the mid and late nineteenth centuries; and historians of the Anglophone, Hispanophone, and Francophone worlds since the 1960s), republicanism has meant somewhat different things to different people. For a history of its shifting uses and meanings (or lack thereof) in the context of United States history, see Dan Rodgers's classic essay "Republicanism: The Career of a Concept" in the Journal of American History 79, no. 1 (June 1992): 11-38; for an analysis of Latin American politics and political cultural that fruitfully blurs the boundaries between liberalism, republicanism, and democracy, see James Sanders, The Vanguard of the Atlantic World: Creating Modernity, Nation, and Democracy in Nineteenth-Century Latin America (Durham: Duke University Press, 2014); for recent long dureé histories of these three related ideas, see Helena Rosenblatt, The Lost History of Liberalism: From Ancient Rome to the Twenty-First Century (Princeton: Princeton University Press, 2018), and James Miller, Can Democracy Work? A Short History of a Radical Idea, from Ancient Athens to Our World (New York: Farrar, Straus and Giroux, 2018).

4. See, among many others, Patricia Nelson Limerick, Legacy of Conquest: The Unbroken Past of the American West (New York: Norton, 1987); James Brooks, Captives and Cousins: Slavery, Kinship, and Community in the Southwest Borderlands (Chapel Hill: University of North Carolina Press, 2002); Ari Kelman, A Misplaced Massacre: Struggling over the Memory of Sand Creek (Cambridge: Harvard University Press, 2013).

5. Jerry Thompson, Cortina: Defending the Mexican Name in Texas (College Station: Texas A \& M, 2007), 8-10; Charles Goldfinch, "Juan N. Cortina 1824-1892: A Re-Appraisal," in Juan N. Cortina: Two Interpretations (New York: Arno, 1974), 17, 30, 33-34, 39 .

6. The most thorough account of Juan Cortina's career is Thompson, Cortina: Defending the Mexican Name in Texas, though as its subtitle suggests, it focuses more on Cortina's impact in Texas than on his role in Mexican politics. Andrew Graybill first drew my attention to the parallels between Cortina and Riel. See Graybill, Policing the Plains: Rangers, Mounties, and the North American Frontier, 1875-1910 (Lincoln: University of Nebraska Press, 2007), 71-81.

7. See, among many others, D. N. Sprague, Canada and the Métis, 1869-1885 (Waterloo, ON: Wilfrid Laurier University Press, 1988); Thomas Flanagan, Louis “David" Riel: Prophet of the New World (Toronto: University of Toronto Press, 1978); George F. G. Stanley, Louis Riel (New York: McGraw-Hill, 1963); Joseph Howard Kinsey, Strange Empire, A Narrative of the Northwest (New York: William Morrow, 1952). 
8. Difficulties on the Southwestern Frontier (36th Congress, 1st session, House of Representatives, Executive Document 52, 1860), 79, 80.

9. Alberto Varon, "Pronouncing Citizenship: Juan Nepomuceno Cortina's War to Be Read," in The Latino Nineteenth Century: Archival Encounters in American Literary History, ed. Rodrigo Lazo and Jesse Alemán (New York: New York University Press, 2016), 192, 206.

10. "Juan Nepomuceno Cortina to the inhabitants of the State of Texas, and especially to those of the city of Brownsville," House Executive Document, 36 th Cong,. 1st sess., H. Exec. Doc., no. 52, ser. 1050 (Washington, D.C., 1860): 71-72.

11. "Declaration of the People of Rupert's Land and the North West," as reprinted in Raymond Huel, ed., The Collected Writings of Louis Riel/Les Escrits Complets de Louis Riel: Volume 1 (University of Alberta Press, 1985): 42-44, quotes from 42. My depictions of Riel's ideology differ from those of some scholars. Michael Witgen characterizes the Red River and North-West rebellions primarily as adaptations of native and particularly Anishinaabeg political traditions, downplaying the extent to which their proclamations clearly trafficked in western ideas of republicanism, and ignoring altogether Riel's distancing of himself from other Métis claims rooted much more clearly in indigeneity. On the other hand, Thomas Flanagan portrays Riel as a Catholic arch-conservative, even theocrat, downplaying these clearly republican notions. Riel is a complicated figure with a long and tumultuous career, who left us extensive poetry, proclamations intended for public consumption, private letters and pleas, and records of a messianic phase. There are, perhaps, contradictions and tensions in these writings, although some of the strands-particularly republicanism and Catholicism - would likely weave together more neatly if we were to import Raul Coronado's idea of a Catholic republicanism and public sphere into French North America. See Michael Witgen, An Infinity of Nations: How the Native New World Shaped Early North America (Philadelphia: University of Pennsylvania Press, 2012), 360; Gerhard Ens, "Prologue to the Red River Resistance: Pre-liminal Politics and the Triumph of Riel," Journal of the Canadian Historical Association 5, no. 1 (1994): 111-23, especially 114-16; Flanagan, "Political Theory of the Red River Resistance," 164; Raul Coronado, A World Not to Come: A History of Latino Writing and Print Culture (Cambridge: Harvard University Press, 2013), esp. 213-6o.

12. On other treatments of Cortina, see Thompson, Cortina, 250; for a recent example of dismissive treatment, see Felipe Fernéndez-Armesto, Our America: A Hispanic History of the United States (New York: Norton, 2014), 169.

13. Marcel Giraud, The Métis in the Canadian West (Edmonton: University of Alberta Press, 1986), 223-24.

14. Gerhard Ens, Homeland to Hinterland: The Changing World of the Red River Metis in the Nineteenth Century (Toronto: University of Toronto Press, 1996), 39-40.

15. A. A. den Otter, Civilizing the Wilderness: Culture and Nature in Pre-Confederation Canada and Rupert's Land (Edmonton: University of Alberta Press, 2012), 152-53.

16. For the Thomistic strain in scholasticism, see Coronado, A World Not to Come, especially 225-27; for the uses of this tradition in the context of struggles for independence in Spanish America, see 229.

17. Coronado, A World Not to Come, 33, 44-46, 175, 209, 217, 220, 298. 
18. Thompson, Cortina, 31, 45, 47, 66; Goldfinch, Juan N. Cortina, 39.

19. Eric Schlereth, "Privileges of Locomotion: Expatriation and the Politics of Southwestern Border Crossing," Journal of American History 100, no. 4 (2014): 995-1020, especially 999, 1006; Jeremy Mumford, "Why Was Louis Riel, a United States Citizen, Hanged as a Canadian Traitor in 1885?," Canadian Historical Review 88, no. 2 (2007): 238-62, esp. 255; Lauren L. Basson, "Savage Half-Breed, French Canadian or White US Citizen? Louis Riel and US Perceptions of Nation and Civilisation," National Identities 7, no. 4 (December 2005): 369-88, 383-84; Wilbur F. Bryant, The Blood of Abel (Hastings, Nebraska: The Post-Gazette Company, 1887), 74.

20. Difficulties on the Southwestern Frontier, 72.

21. Omar S. Valerio Jiménez, River of Hope: Forging Identity and Nation in the Rio Grande Borderlands (Durham: Duke University Press), 229.

22. Jerry Thompson, Vaqueros in Blue and Gray (College Station: Texas A \& M, 2000), $81,87,94,97,102 ; 118 ; 143$; Valerio Jiménez, River of Hope, 249-50.

23. See the discussion of Confederate dismissal of Tejano Unionist sentiment in Valerio-Jiménez, River of Hope, 249; Clarence Clarendon's characterization of Cortina and other border Mexican unionists in Clarendon, "Mexican Unionists: A Forgotten Incident of the War Between the States," New Mexico Historical Review 39, no. 1 (1964): 32-39, especially 33; and Jerry Thompson's general lack of interest in exploring the ideology of Mexican pro-unionists in Vaqueros in Blue and Gray, passim.

24. Quoted in Valerio-Jimenez, River of Hope, 252, 257.

25. Alice Baumgartner, "Teodoro Zamora's Commission," New York Times Disunion Blog, January 6, 2014, http://opinionator.blogs.nytimes.com/2014/o1/o6/teodoro -zamoras-commission/ (accessed June 23, 2015). My thanks to Baumgartner for sharing her transcription of Teodoro Zamora's letterbook, from the Archivo Genaro Estrada, from which the quotes (her transcription and translation from the original Spanish) are taken.

26. See especially Maier, "Consigning the Twentieth Century to History," 821-24.

27. Quotations in Observations on the Commerce of Spain with Her Colonies in Time of War (Philadelphia: James Carey, 1800), 30-31, 20 (emphasis in original). Also see Coronado, A World Not to Come, 128-29; 153, 172. Coronado argues that the unnamed author was surely Spanish diplomat Casa Irujo.

28. Wm. Lloyd Garrison to Louisa Loring, Boston, July 30, 1847, folder 36, Ellis Gray Loring Family Papers, 1830-1919, Schlesinger Library, Harvard, A-115. Quote courtesy of Kate Masur.

29. Giraud, Métis in the Canadian West, 2:219-20, 234; den Otter, Civilizing the Wilderness, 138.

30. Andrew Isbister, A Few Words on the Hudson's Bay Company (London: C. Gilpin, 1846), 1, 7, 10.

31. Quoted in Coronado, A World Not to Come, 277-78.

32. Justin H. Smith, "La Republica de Rio Grande," American Historical Review 25 (July 1920): 666.

33. Plan del Campo de la Loba, September 3, 1851, reproduced in Román Iglesias González, Planes politicos, proclamas, manifiestos y otros documentors de la Independen- 
cia al México modern, 1812-1940 (Universidad Nacional Autónoma de México, Instituto de Estudios Históricos, no. 74, 1998), 284-85.

34. Octavio Herrera Pérez, "El regimen de excepción fiscal y la formación histórica de la frontera norte de México," in Manuel Ceballos Ramírez, ed., Encuentro en la frontera: mexicanos y norteamericanos en un espacio común (Tijuana: Colegio de la Frontera, 2001), 199, 204; Sonia García Ochoa, "Baja California: Historia de la Zona Libre," El Sol de Tijuana, July 27, 2009; Samuel E. Bell and James M. Smallwood, "Zona Libre: Trade and Diplomacy on the Mexican Border, 1858-1905," Arizona and the West 24, no. 2 (1982): 119-52.

35. Giraud, Métis in the Canadian West, 212-14.

36. Den Otter, Civilizing the Wilderness, 151, 158-59.

37. Den Otter, Civilizing the Wilderness, 148-50, 156-57; Ens, "Prologue to the Red River Resistance," 116; see provision 20 in the "List of Rights" issued December 8, 1869, as reproduced at http://www3.sympatico.ca/rd.fournier/inter.canada/doc/metisi.htm. 